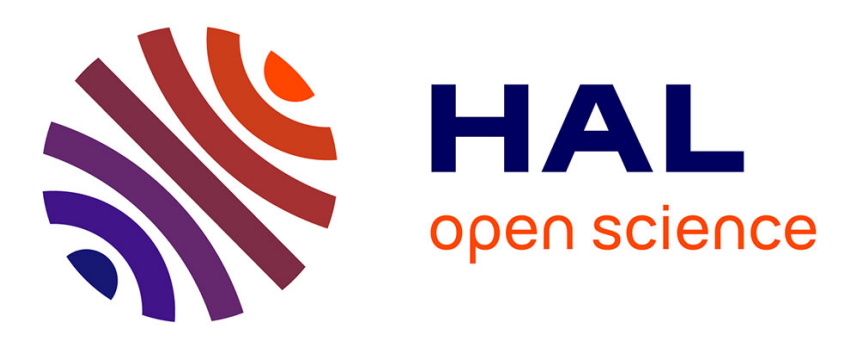

\title{
Study of the oxygen diffusion on three-way catalysts: a kinetic model
}

\author{
Arvaidas Galdikas, Claude Descorme, Daniel Duprez, Fei Dong, Hirofumi \\ Shinjoh
}

\section{- To cite this version:}

Arvaidas Galdikas, Claude Descorme, Daniel Duprez, Fei Dong, Hirofumi Shinjoh. Study of the oxygen diffusion on three-way catalysts: a kinetic model. Topics in Catalysis, 2004, Proceedings of the 6th Congress on Catalysis and Automotive Pollution Control (CAPoC6), 30-31 (1-4), pp.405-409. 10.1023/B:TOCA.0000029782.78561.47 . hal-00007460

\section{HAL Id: hal-00007460 \\ https://hal.science/hal-00007460}

Submitted on 8 Oct 2021

HAL is a multi-disciplinary open access archive for the deposit and dissemination of scientific research documents, whether they are published or not. The documents may come from teaching and research institutions in France or abroad, or from public or private research centers.
L'archive ouverte pluridisciplinaire HAL, est destinée au dépôt et à la diffusion de documents scientifiques de niveau recherche, publiés ou non, émanant des établissements d'enseignement et de recherche français ou étrangers, des laboratoires publics ou privés. 


\title{
Study of the oxygen diffusion on three-way catalysts: a kinetic model
}

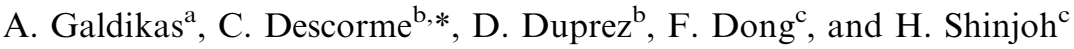 \\ ${ }^{a}$ Department of Physics, Kaunas University of Technology, 50 Studentu Street, LT3031 Kaunas, Lithuania \\ ${ }^{\mathrm{b}}$ LACCO, UMR 6503 CNRS/University of Poitiers, Faculté des Sciences, 40 Avenue du Recteur Pineau, 86022 Poitiers Cedex, France \\ ${ }^{\mathrm{c}}$ Toyota Central R\&D Labs. Inc, Applied Catalysis Division, Nagakute, Aichi 480-1192, Japan
}

\begin{abstract}
A computer model was developed to take into account all the phenomena that can occur in ${ }^{18} \mathrm{O} /{ }^{16} \mathrm{O}$ isotopic exchange over $\mathrm{Pt} /$ $\mathrm{CeZrO}_{x}$ materials: adsorption/desorption on the metal, surface and bulk $\mathrm{O}$ diffusion. Discriminating each step of the exchange process is no longer necessary: kinetic parameters and $\mathrm{O}$ diffusivity can be calculated in a single experiment.
\end{abstract}

KEY WORDS: cerium-zirconium oxides; ${ }^{18} \mathrm{O} /{ }^{16} \mathrm{O}$ isotopic exchange; oxygen diffusion; oxygen storage capacity (OSC).

\section{Introduction}

Ceria-zirconia solid solutions are well-known oxygen storage components used in three-way catalyst formulations [1-7]. During the oxygen storage process, diffusion was shown to be one of the key parameters. This work deals with the determination of oxygen surface and bulk diffusion coefficients in $\mathrm{Ce}_{x} \mathrm{Zr}_{1-x} \mathrm{O}_{2}$ oxides. The method is based on isotopic exchange measurements between ${ }^{18} \mathrm{O}_{2}$ molecules, initially introduced in the gas phase, and ${ }^{16} \mathrm{O}$ atoms from the support. In that case, it was shown that metal particles act as $\mathrm{O}$ atoms portholes for the subsequent migration of oxygen on the oxide [8]. Earlier diffusion coefficient determinations were based on Kramer's and Kakioka's models $[9,10]$. However, these models, initially developed for $\mathrm{Al}_{2} \mathrm{O}_{3}$ and $\mathrm{V}_{2} \mathrm{O}_{5}$, could not properly describe high oxygen mobility solids [11]. For that reason, a new kinetic model, describing the overall exchange process, was required.

\section{Experimental}

Isotopic exchange experiments were carried out in a home made apparatus previously described [8-12]. It consisted of a closed reactor (about $50 \mathrm{~mL}$ ) equipped with a recirculating pump to avoid any diffusion effect in the gas phase. The reactor was connected to a quadrupole mass spectrometer for the gas phase composition analysis $(m / e=32,34,36$ as well as 28 for leak tests). Two kinds of experiments were carried out: heteroexchange and homoexchange.

Heteroexchange experiments are carried out using pure ${ }^{18} \mathrm{O}_{2}$ (50 mbar). The rates for ${ }^{18} \mathrm{O}_{2}$ "consumption" and ${ }^{18} \mathrm{O}^{16} \mathrm{O}$ and ${ }^{16} \mathrm{O}_{2}$ "formation" are derived for the MS analysis. Generally, heteroexchange occurs via simple exchange, i.e. atom per atom:

\footnotetext{
*To whom correspondence should be addressed.

E-mail: claude.descorme@univ-poitiers.fr
}

$$
\begin{aligned}
& { }^{18} \mathrm{O}_{2} \text { (gas) }+{ }^{16} \mathrm{O}(\text { solid }) \rightarrow{ }^{18} \mathrm{O}^{16} \mathrm{O}(\text { gas })+{ }^{18} \mathrm{O}(\text { solid }) \\
& \left.{ }^{18} \mathrm{O}^{16} \mathrm{O}(\text { gas })+{ }^{16} \mathrm{O}(\text { solid }) \rightarrow{ }^{16} \mathrm{O}_{2} \text { (gas }\right)+{ }^{18} \mathrm{O}(\text { solid })
\end{aligned}
$$

However, specially with ceria-based oxides, it was shown that multiple exchange occurs [5]. In that case, the two oxygen atoms can be exchanged at once. Multiple exchange is responsible for the very initial formation of ${ }^{16} \mathrm{O}_{2}$ in gas phase:

$$
\left.{ }^{18} \mathrm{O}_{2} \text { (gas) }+{ }^{16} \mathrm{O} \bullet{ }^{16} \mathrm{O} \text { (solid }\right) \rightarrow{ }^{16} \mathrm{O} \text { (gas) }+{ }^{18} \mathrm{O} \bullet \bullet{ }^{18} \mathrm{O} \text { (solid) }
$$

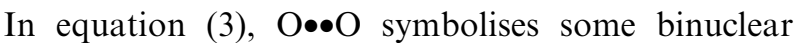
oxygen species, most probably superoxides $[5,13,14]$.

For homoexchange experiments, a $50-50 \%$ ${ }^{18} \mathrm{O}_{2}+{ }^{16} \mathrm{O}_{2}$ mixture is introduced on the catalyst sample (about $20 \mathrm{mg}$ ). Such experiments are carried out to determine the oxygen equilibration rate, that is the ability of the metal particles to activate the oxygen molecules (adsorption/desorption):

$$
{ }^{18} \mathrm{O}_{2} \text { (gas) }+{ }^{16} \mathrm{O}_{2} \text { (gas) } \rightarrow 2{ }^{18} \mathrm{O}^{16} \mathrm{O}(\text { gas })
$$

In most cases, adsorption/desorption on metals (especially $\mathrm{Rh}$ and $\mathrm{Pt}$ ) is much faster than the $\mathrm{O}$ diffusion on the oxide supports [15]. In a pure homoexchange process, oxygen atoms from the solid do not participate in the reaction. Consequently, the fraction of ${ }^{18} \mathrm{O}$ atoms in gas phase remains constant $\left(\alpha_{\mathrm{g}}=0.5\right)$. However, for cerium-based materials, $\mathrm{O}$ diffusion is so fast that heteroexchange also occurs upon homoexchange experiments. For that reason, kinetic modelling should take into account the two processes (adsorption and diffusion) with a similar rate level.

Three $\mathrm{Ce}_{x} \mathrm{Zr}_{1-x} \mathrm{O}_{2}$ samples, with $x=0.5$, were synthesized as described earlier [16]. CZ-O was prepared from the hydrolysis of $\mathrm{ZrO}\left(\mathrm{NO}_{3}\right)_{2}$ with an aqueous ammonia solution in the presence of a fine ceria powder. This solid was dried at $90{ }^{\circ} \mathrm{C}$ and 
Table 1

Physical and chemical characteristics of the catalysts

\begin{tabular}{|c|c|c|c|c|}
\hline Catalyst & $\begin{array}{l}\text { Surface area } \\
\qquad\left(\mathrm{m}^{2} \mathrm{~g}^{-1}\right)\end{array}$ & $\begin{array}{l}\text { Metal particle } \\
\text { size }(\mathrm{nm})\end{array}$ & $\begin{array}{c}\text { Metal dispersion } \\
(\%)\end{array}$ & $\begin{array}{c}\text { Oxide grain } \\
\text { size }(\mathrm{nm})\end{array}$ \\
\hline $1 \% \mathrm{Pt} / \mathrm{CZ}-\mathrm{D}$ & 37 & 2 & 59 & 20 \\
\hline $1 \% \mathrm{Pt} / \mathrm{CZ}-\mathrm{O}$ & 104 & 5.2 & 23 & 10 \\
\hline $1 \% \mathrm{Pt} / \mathrm{CZ}-\mathrm{R}$ & 3 & 59 & 2 & 200 \\
\hline
\end{tabular}

calcined at $500{ }^{\circ} \mathrm{C}$ for $5 \mathrm{~h}$ in air. CZ-R was prepared as $\mathrm{CZ}-\mathrm{O}$ but the solid was first reduced at $1200{ }^{\circ} \mathrm{C}$ in a $\mathrm{CO}$ stream before re-oxidation at $500{ }^{\circ} \mathrm{C}$ in air. $\mathrm{CZ}-\mathrm{D}$ was prepared by high energy ball milling of $\mathrm{CeO}_{2}$ and $\mathrm{ZrO}_{2}$ powders [17]. $1 \% \mathrm{Pt} / \mathrm{CZ}$ catalysts were prepared by conventional impregnation using $\mathrm{Pt}\left(\mathrm{NH}_{3}\right)_{2}\left(\mathrm{NO}_{2}\right)_{2}$ as platinum precursor. They were calcined at $500{ }^{\circ} \mathrm{C}$ for $3 \mathrm{~h}$ in air. BET areas were determined by $\mathrm{N}_{2}$ adsorption using a Micro Sorb 4232II apparatus (Micro Data Co Ltd). X-ray diffraction was used to identify the crystalline phases and to determine the mean particle size of these oxides. XRD patterns were collected using a Rigaku RINT2200 diffractometer. CZ-D and CZ-R appeared to be monophasic $\mathrm{Ce}_{0.5} \mathrm{Zr}_{0.5} \mathrm{O}_{2}$ solid solutions with a cubic structure while $\mathrm{CZ}-\mathrm{O}$ was shown to be a mixture of cubic $\mathrm{CeO}_{2}$ and tetragonal $\mathrm{ZrO}_{2}$ phases [16]. The catalyst samples were also examined by TEMEDX in a HITACHI $2000 \mathrm{H}$ microscope. The degree of incorporation of $\mathrm{Zr}$ ions in the ceria lattice was higher for $\mathrm{CZ}-\mathrm{R}$ than for $\mathrm{CZ}-\mathrm{D}$. The $\mathrm{Ce} / \mathrm{Zr}$ ratio, determined by EDX on 10-20 points, was almost constant and equal to 1 for $\mathrm{CZ}-\mathrm{R}$ while the $\mathrm{Ce} / \mathrm{Zr}$ ratio varied from 0.2 to 1.4 for CZ-D [16]. As a result, the homogeneity of the samples decreased as follows: $\mathrm{CZ}-\mathrm{R}>$ CZ-D > CZ-O.

TEM was also used to determine the mean platinum particles size in parallel with XRD. The Pt(331) diffraction peak was used for $\mathrm{Pt} / \mathrm{CZ}-\mathrm{O}$. The main characteristics are given in table 1.

From the data reported in table 1, additional parameters could be calculated such as: the number of metal particle $\left(N_{\mathrm{m}}\right)$, the number of oxide grains $\left(N_{\mathrm{s}}\right)$ per $\mathrm{m}^{2}$ of support and the mean distance between metal particles (assumed to be equal to $N_{\mathrm{m}}{ }^{-1 / 2}$ ). The nanometric pictures of the catalyst sample drawn from these values are shown in figure 1. Statistically, $\mathrm{Pt} / \mathrm{CZ}-\mathrm{D}$ has virtually one $\mathrm{Pt}$ particle on every oxide grain. The other two catalysts certainly have oxide grains without $\mathrm{Pt}$ particles on top. Several factors may influence the isotopic exchange rate: the platinum particle size, the homogeneity of the $\mathrm{Ce}_{x} \mathrm{Zr}_{1-x} \mathrm{O}_{2}$ solid solutions. Previous works have shown that homoexchange was significantly faster on the biggest platinum particles (typically 5-10 $\mathrm{nm}$ ) compared to the smallest ones (1-2 nm) [15]. Moreover, O diffusion is faster on ceria than on zirconia [8]. This might affect the performances of $\mathrm{Pt} / \mathrm{CZ}-\mathrm{O}$ where a mixture of $\mathrm{CeO}_{2}$ and $\mathrm{ZrO}_{2}$ crystallites were detected.

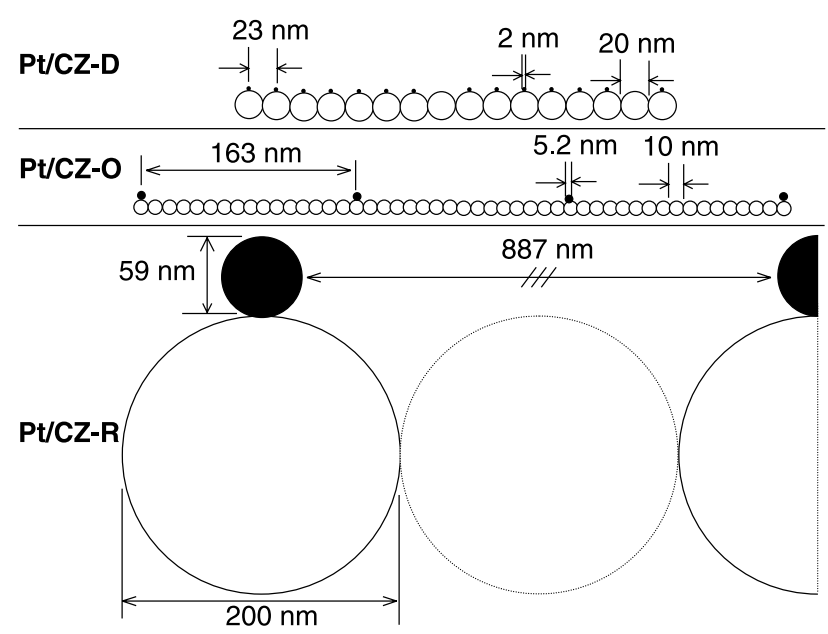

Figure 1. Nanometric pictures of the three catalysts.

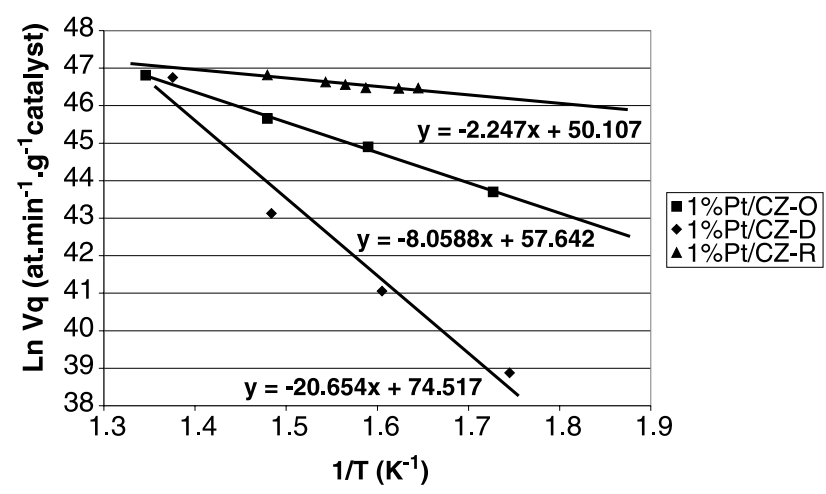

Figure 2. Arrhenius plot of isotopic homoexchange.

\section{Results}

The results obtained upon homoexchange are presented below. On figure 2, the evolution of the initial homoexchange rates as a function of temperature $(\mathrm{K})$ is given in Arrhenius coordinates. Experiments were carried out in the $300-460{ }^{\circ} \mathrm{C}$ temperature range.

$\mathrm{Pt} / \mathrm{CZ}-\mathrm{R}$ was shown to be more active in the homoexchange reaction than $1 \% \mathrm{Pt} / \mathrm{CZ}-\mathrm{D}$ and $1 \% \mathrm{Pt} /$ $\mathrm{CZ}-\mathrm{O}$. This reactivity order is true over the whole temperature range. Looking at the metal dispersion, it is confirmed that the larger the platinum particles, the higher the reactivity in the oxygen homoexchange reaction (table 2 ). $\mathrm{Pt} / \mathrm{CZ}-\mathrm{R}$ has a surprisingly high activity. This specific behaviour was proposed to be 
Table 2

Intrinsic homoexchange rates at $300{ }^{\circ} \mathrm{C}$

\begin{tabular}{lccc}
\hline & $\begin{array}{c}\text { Metal } \\
\text { dispersion } \\
(\%)\end{array}$ & $\begin{array}{c}\text { Rate of } \\
\text { equilibration } \\
\text { at } 300^{\circ} \mathrm{C} \\
\left(\text { at } \mathrm{O} \mathrm{s}^{-1} \mathrm{~m}^{-2} \text { metal }\right)\end{array}$ & $\begin{array}{c}\text { Apparent } \\
\text { activation } \\
\text { energy } \\
\left(\mathrm{kJ} \mathrm{mol}^{-1}\right)\end{array}$ \\
\hline $1 \% \mathrm{Pt} / \mathrm{CZ}-\mathrm{D}$ & 59 & $5.8 \times 10^{14}$ & 172 \\
$1 \% \mathrm{Pt} / \mathrm{CZ}-\mathrm{O}$ & 23 & $2.5 \times 10^{17}$ & 67 \\
$1 \% \mathrm{Pt} / \mathrm{CZ}-\mathrm{R}$ & 2 & $3.9 \times 10^{19}$ & 19
\end{tabular}

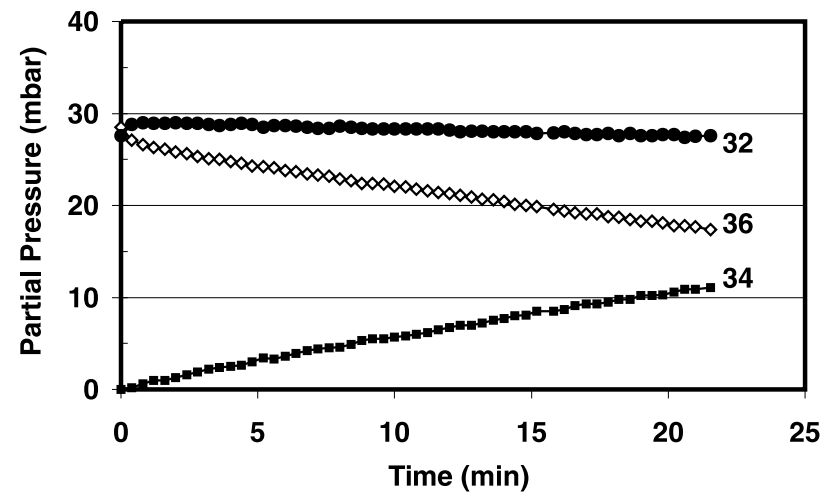

Figure 3. Evolution with time of the partial pressures of ${ }^{18} \mathrm{O}_{2},{ }^{16} \mathrm{O}_{2}$ and ${ }^{18} \mathrm{O}^{16} \mathrm{O}$ upon homoexchange at $412{ }^{\circ} \mathrm{C}$ on a $1 \% \mathrm{Pt} / \mathrm{CZ}-\mathrm{R}$ catalyst.

responsible for the very good catalytic performances of such a catalytic formulation [16]. In parallel, it appeared that $\alpha_{\mathrm{g}}$ decreased continuously with time on stream. It was concluded that heteroexchange also occurred upon homoexchange experiments. An example is shown in figure 3 . In fact, $\mathrm{P}_{32}$ appears to be quite constant while $\mathrm{P}_{36}$ regularly decreases with time. Obviously, there is a continuous diffusion of ${ }^{16} \mathrm{O}$ atoms from the support to the metal particles upon homoexchange.

The results obtained on the three $\mathrm{Pt} / \mathrm{CZ}$ catalysts in the oxygen heteroexchange reaction are summarized in figure 4. Pt/CZ-R also appears to be the most active catalyst in oxygen heteroexchange reaction. Two temperature domains are clearly visible on figure 4. At low temperature, the reaction has a relatively high activation energy: 56, 81 and $172 \mathrm{~kJ} \mathrm{~mol}^{-1}$ for Pt/CZ-R, Pt/CZ-D and $\mathrm{Pt} / \mathrm{CZ}-\mathrm{O}$ respectively. In this temperature range, the reaction is normally controlled by the oxygen adsorption/desorption process on the metal particles [8]. However, a comparison with the activation energies obtained in the homoexchange reaction, particularly the inversion between $\mathrm{Pt} / \mathrm{CZ}-\mathrm{O}$ and $\mathrm{Pt} / \mathrm{CZ}-\mathrm{D}$, shows that the mechanism of such reactions is complex and involves several steps (adsorption/desorption; surface diffusion; bulk diffusion) that might occur at the same time at comparable rates.

All these results demonstrate that a detailed kinetic modelling of all the steps involved upon exchange is required for the processing of the raw data.

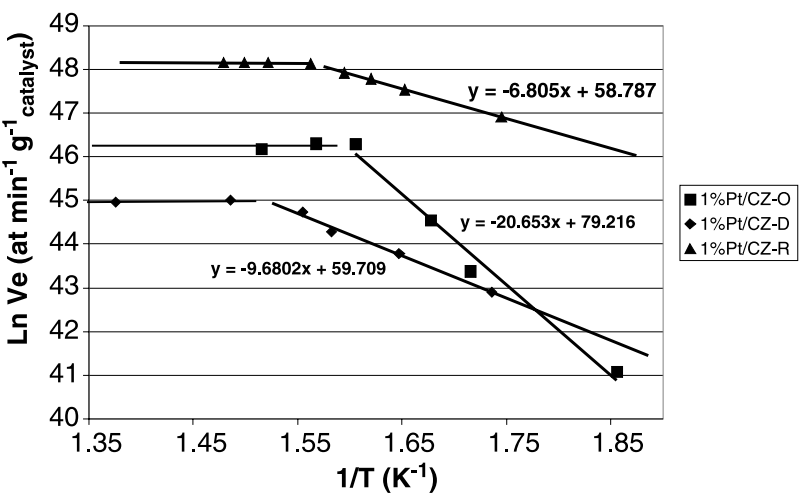

Figure 4. Arrhenius plot of isotopic heteroexchange.

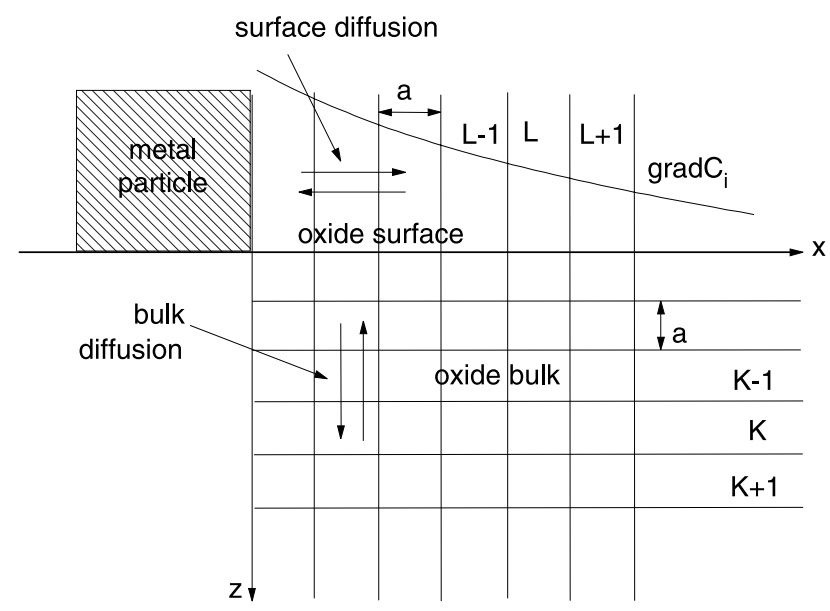

Figure 5. Geometrical model used for finite-difference calculations.

\section{Kinetic modelling}

In the earlier calculations, only the initial exchange rates were taken into account because it was possible to carry out experiments under such conditions where one of the steps of the exchange process (adsorption/ desorption, surface diffusion, bulk diffusion) was ratecontrolling. This is no longer possible with catalysts presenting a very high oxygen mobility. In order to describe the isotopic exchange process on noble metal supported $\mathrm{Ce}_{x} \mathrm{Zr}_{1-x} \mathrm{O}_{2}$ catalysts, a new computational program "PLATINA" was developed. The following steps were considered: (i) oxygen adsorption/desorption on the metal particles, (ii) oxygen diffusion at the surface and in the bulk of the oxide and (iii) possible direct exchange between the support and the gas phase.

For the calculations, (i) metal particles were assumed to be square-shaped, (ii) the oxide surface around the metal particles was artificially divided as square-shaped rings $(L)$ and (iii) the oxide bulk was divided in layers $(K)$. Oxygen diffusion may be described using the second Fick's law. The geometrical model used for the finitedifference resolution of the Fick's law is shown in figure 5. 
Table 3

Parameters deduced from kinetic modelling

\begin{tabular}{|c|c|c|c|c|c|c|}
\hline Catalyst & $\mathrm{Pt} / \mathrm{CZ}-\mathrm{D}$ & $\mathrm{Pt} / \mathrm{CZ}-\mathrm{O}$ & $\mathrm{Pt} / \mathrm{CZ}-\mathrm{R}$ & $\mathrm{Pt} / \mathrm{CZ}-\mathrm{D}$ & $\mathrm{Pt} / \mathrm{CZ}-\mathrm{O}$ & $\mathrm{Pt} / \mathrm{CZ}-\mathrm{R}$ \\
\hline Temperature $\left({ }^{\circ} \mathrm{C}\right)$ & 334 & 323 & 332 & 400 & 406 & 403 \\
\hline Homoexchange $R\left(\mathrm{~m}^{2} / \mathrm{mol} \mathrm{s}\right)$ & 123 & 3950 & 49,400 & 1049 & 89,000 & 136,000 \\
\hline Surface diffusion $D_{\mathrm{s}}\left(\times 10^{-20} \mathrm{~m}^{2} \mathrm{~s}^{-1}\right)$ & 1.7 & 109 & 1450 & 68 & 1490 & 3080 \\
\hline Bulk diffusion $D_{\mathrm{b}}\left(\times 10^{-23} \mathrm{~m}^{2} \mathrm{~s}^{-1}\right)$ & 0.34 & 4.5 & 36 & 2 & 37 & 77 \\
\hline
\end{tabular}

The variation of the concentration in ${ }^{16} \mathrm{O}$ atoms upon surface and bulk diffusion are respectively given by

$$
\begin{aligned}
& \frac{\mathrm{d} c_{16}^{(1, L)}}{\mathrm{d} t}=\frac{D_{\mathrm{s}}}{a^{2}}\left[A^{(L-1)}\left(c_{16}^{(1, L-1)}-c_{16}^{(1, L)}\right)-A^{(L)}\left(c_{16}^{(1, L)}-c_{16}^{(1, L+1)}\right)\right] \\
& \frac{\mathrm{d} c_{16}^{(K, L)}}{\mathrm{d} t}=\frac{\mathrm{D}_{\mathrm{b}}}{a^{2}}\left[B^{(K-1)}\left(c_{16}^{(K-1, L)}-c_{16}^{(K, L)}\right)-B^{(K)}\left(c_{16}^{(K, L)}-c_{16}^{(K+1, L)}\right)\right]
\end{aligned}
$$

with the following conditions that fix the net direction of the diffusion flow: tions in the isotopic exchange reactions. Considering bulk diffusion coefficient values, one could conclude that oxygen is pretty immobile in $1 \% \mathrm{Pt} / \mathrm{CZ}-\mathrm{D}$ whatever the temperature. At $300-330{ }^{\circ} \mathrm{C}$, bulk diffusion coefficients measured for $1 \% \mathrm{Pt} / \mathrm{CZ}-\mathrm{R}$ and $1 \% \mathrm{Pt} / \mathrm{CZ}-\mathrm{O}$ are comparable to the one previously measured on "equivalent" formulations. Finally, the high activity of $1 \% \mathrm{Pt} / \mathrm{CZ}-\mathrm{R}$ in the isotopic exchange reactions could be directly related to both a high oxygen surface mobility and a high bulk

$$
A^{(L)}=\left\{\begin{array}{ll}
\frac{S^{(L+1)}}{S^{(L)}}, & \text { if } c_{i}^{(L)}-c_{i}^{(L+1)}>0 \\
\frac{S^{(L)}}{S^{(L+1)}}, & \text { if } c_{i}^{(L)}-c_{i}^{(L+1)}<0
\end{array} \text { and } B^{(K)}= \begin{cases}\frac{S^{(K+1)}}{S^{(K)}}, & \text { if } c_{i}^{(L, K)}-c_{i}^{(L, K+1)}>0 \\
\frac{S^{(K)}}{S^{(K+1)}}, & \text { if } c_{i}^{(L, K)}-c_{i}^{(L, K+1)}<0\end{cases}\right.
$$

with $S^{(L)}=4 N[d+(L-1) a] a$ and $S^{(K)}=S_{\mathrm{ox}}\left(1-L \frac{a}{D_{\mathrm{ox}}}\right)$

where $\mathrm{S}_{o x}$ is the oxide surface and $D_{\mathrm{ox}}$ is the oxide grain size to take into account the decrease of $S^{(K)}$ from the exterior to the interior of the oxide grain.

Kinetic modelling was successfully applied to determine both kinetic and thermodynamic characteristics of the catalysts under study. Oxygen diffusion coefficients and activation energies were systematically calculated from the simulation of the raw data, that is the evolution as a function of time of the oxygen isotopomers' partial pressures.

From both homoexchange and heteroexchange experiments, it was concluded that the activity of platinum in the oxygen activation is higher in $1 \% \mathrm{Pt} /$ $\mathrm{CZ}-\mathrm{R}$ than in $1 \% \mathrm{Pt} / \mathrm{CZ}-\mathrm{O}$ and $1 \% \mathrm{Pt} / \mathrm{CZ}-\mathrm{D}$. In fact, $1 \% \mathrm{Pt} / \mathrm{CZ}-\mathrm{D}$ is very little active. This activity ranking correlates with the platinum particle size: the bigger the particles, the higher the activity. This observation is in perfect agreement with previous results [12,15]. A comparison between the different catalysts has been made at two different temperatures around 330 and $400{ }^{\circ} \mathrm{C}$. The results of the kinetic modelling are given in table 3 . From heteroexchange experiments, surface and bulk diffusion were shown to be much faster on $1 \% \mathrm{Pt}$ CZ-R than on $1 \% \mathrm{Pt} / \mathrm{CZ}-\mathrm{O}$ and $1 \% \mathrm{Pt} / \mathrm{CZ}-\mathrm{D}$ in the whole temperature range.

In fact, surface diffusion on $1 \% \mathrm{Pt} / \mathrm{CZ}-\mathrm{D}$ was $2-3$ orders of magnitude slower than on the other two samples. At $330{ }^{\circ} \mathrm{C}$, surface diffusion coefficient was in the $10^{-18} \mathrm{~m}^{2} \mathrm{~s}^{-1}$ for $1 \% \mathrm{Pt} / \mathrm{CZ}-\mathrm{R}$ and $1 \% \mathrm{Pt} / \mathrm{CZ}-\mathrm{O}$, which is a common range for the most active formula- oxygen mobility. This behaviour can be paralleled with the one of $\mathrm{CZ}$ catalysts exhibiting better OSC properties after redox cycling at high temperature [18].

\section{Conclusions}

A kinetic modelling of the ${ }^{18} \mathrm{O} /{ }^{16} \mathrm{O}$ isotopic exchange was developed in order to derive the parameters representative for oxygen diffusion at the surface and in the bulk of $\mathrm{Pt} / \mathrm{Ce}_{0.5} \mathrm{Zr}_{0.5} \mathrm{O}_{2}$ catalysts. For these catalysts, oxygen mobility is so high that the different steps of the exchange cannot be easily discriminated using a simple model.

The results obtained using PLATINA show that a high temperature pre-treatment under $\mathrm{CO}$ leads to an extremely active catalyst in the isotopic exchange reaction with an exceptionally high oxygen mobility.

\section{References}

[1] M.A. Harkonen, E. Aitta, A. Lahti, M. Luoma and T. Maunula, SAE Paper 910846.

[2] J.-P. Cuif, G. Blanchard, O. Touret, A. Seigneurin, M. Marczi and E. Quéméré, SAE Paper 970463.

[3] M. Ozawa, J. Alloys Compd. 275-277 (1998) 886.

[4] S. Rossignol, Y. Madier and D. Duprez, Catal. Today 50 (1999) 261.

[5] Y. Madier, C. Descorme, A.-M. Le Govic and D. Duprez, J. Phys. Chem. 103 (1999) 10999.

[6] A. Suda, Y. Ukyo, H. Sobukawa and M. Sugiura, J. Ceram. Soc. Japan 110 (2002) 126. 
[7] C. Descorme and D. Duprez, in: Catalysis by Ceria and related Materials, A. Trovarelli (Ed.), Catalytic Science Series, Vol. 2, Imperial College Series, London (2002).

[8] D. Martin and D. Duprez, J. Phys. Chem. 100 (1996) 9429.

[9] R. Kramer and M. Andre, J. Catal. 58 (1979) 287.

[10] H. Kakioka, V. Ducarme and S.J. Teichner, J. Chim. Phys. 68 (1971) 1715.

[11] S. Bedrane, C. Descorme and D. Duprez, Catal. Today 73 (2002) 233; 75 (2002) 401.

[12] D. Duprez, Stud. Surf. Sci. Catal. 112 (1997) 13.

[13] S. Rossignol, F. Gerard and D. Duprez, J. Mater. Chem. 9 (1999) 1615.
[14] F. Fernández-García, A. Martínez-Arias, A. Iglesias-Juez, C. Belver, A.B. Hungría, J.C. Conesa and J. Soria, J. Catal. 194 (2000) 385 .

[15] C. Descorme and D. Duprez, Appl. Catal. A: Gen. 202 (2000) 231

[16] T. Tanabe, A. Suda, C. Descorme, D. Duprez, H. Shinjoh and M. Sugiura, Stud. Surf. Sci. Catal. 138 (2001) 135.

[17] A. Suda, T. Kandori, Y. Ukyo, H. Sobukawa and M. Sugiura, J. Ceram. Soc. Japan 108 (2000) 473.

[18] F. Fally, V. Perrichon, H. Vidal, J. Kaspar, G. Blanco, J.M. Pintado, S. Bernal, G. Colon, M. Daturi and J.C. Lavalley, Catal. Today 59 (2000) 373 . 